\title{
Morphological and molecular identification of ticks infesting Boa constrictor (Squamata, Boidae) in Manaus (Central Brazilian Amazon)
}

\author{
Identificação morfológica e molecular de carrapatos coletados de jiboias (Boa constrictor)
}

(Squamata, Boidae) da zona urbana de Manaus

Leonardo Costa Fiorini ${ }^{1 *}$; Adriana Bentes Craveiro ${ }^{2}$; Márcia Cristina Mendes ${ }^{1}$;

Laerzio Chiesorin Neto ${ }^{3}$; Ronis Da Silveira ${ }^{2}$

\author{
${ }^{1}$ Laboratório de Parasitologia Animal, Instituto Biológico - IB, São Paulo, SP, Brasil \\ ${ }^{2}$ Laboratório de Zoologia - Aplicada à Conservação, Departamento de Biologia, Instituto de Ciências Biológicas, Universidade \\ Federal do Amazonas - UFAM, Manaus, AM, Brasil \\ ${ }^{3}$ Refúgio da Vida Silvestre Sauim Castanheiras, Manaus, AM, Brasil
}

Received June 6, 2014

Accepted August 8, 2014

\begin{abstract}
The Boa constrictor is one of the world's largest vertebrate carnivores and is often found in urban areas in the city of Manaus, Brazil. The morphological identification of ticks collected from 27 snakes indicated the occurrence of Amblyomma dissimile Koch 1844 on all individuals sampled. In contrast, Amblyomma rotundatum Koch was found on only two snakes. An analysis of the $16 \mathrm{~S}$ rRNA molecular marker confirmed the morphological identification of these ectoparasites.
\end{abstract}

Keywords: Amblyomma dissimile, Amblyomma rotundatum, Boa constrictor, Manaus, Brazil.

\section{Resumo}

A jiboia (Boa constrictor), vertebrado carnívoro, tem sido encontrada em abundância na área urbana de Manaus. A identificaçáo morfológica dos carrapatos coletados em 27 dessas serpentes verificou a ocorrência de Amblyomma dissimile Koch 1844, em todos os exemplares avaliados e a presença de Amblyomma rotundatum Koch 1844, em duas dessas serpentes. A análise do marcador $16 \mathrm{~S}$ rRNA confirma a identificaçâo morfológica das espécies $A$. rotundatum e A. dissimile e apresenta novas sequências destes organismos.

Palavras-chave: Amblyomma dissimile, Amblyomma rotundatum, Boa constrictor, Manaus, Brasil.

\section{Introduction}

The Boa constrictor is one of the largest snakes in the world and can reach a total length of over four meters. This predator with terrestrial and semi-arboreal habits consumes lizards, birds and mammals (CUNHA \& NASCIMENTO, 1978; HENDERSON et al., 1995; BERNARDE, 2004; QUICK et al., 2005; PIZZATTO \& MARQUES, 2007; PIZZATTO et al., 2009). Boa constrictor occur throughout Brazil and can be found in urban environments (MARTINS \& OLIVEIRA, 1998; PIZZATTO \& MARQUES, 2007; BERNARDE \& ABE, 2006; BENTES, 2013). In fact, specimens are often caught in the city of Manaus, AM (central Brazilian Amazon), which has a population of almost two million (IBGE, 2012). In this region there are

*Corresponding author: Leonardo Costa Fiorini, Laboratório de Parasitologia Animal, Instituto Biológico APTA SAA/SP, Av. Conselheiro Rodrigues Alves, 1252, Vila Mariana, CEP 04014-002, São Paulo, SP, Brasil, e-mail: lcfiorini@ biologico.sp.gov.br hundreds of rainforest fragments measuring 1 to 600 ha very close to urban areas. This combination of environments favors the parasitism of snakes by ticks (BENTES, 2013), which may be related to local parasitism dynamics (DAVIS et al., 2012). Despite this fact, only one earlier study has reported specimens of $A$. dissimile parasitizing a Boa constrictor captured in 1975 in an "INPA secondary forest" (ADIS, 1981).

The present study identifies tick species parasitizing Boa constrictor in urban areas of the city of Manaus, AM, with the aid of morphological and molecular tools.

\section{Materials and Methods}

All the ticks found attached to the body surfaces of Boa constrictor captured between September 2010 and November 2012 were collected by the Municipal Secretariat for Environment and 
Sustainability (SEMMAS) in urban areas in the city of Manaus, AM ( $3^{\circ} 6^{\prime} 7^{\prime \prime} \mathrm{S}$ and $60^{\circ} 1^{\prime} 30^{\prime}$ W). Most of the ticks were found attached to the head and the first $10 \mathrm{~cm}$ of the body. The ticks were removed manually using tweezers and stored in $70 \%$ alcohol for transfer to the laboratory, where males, females and nymphs were identified under a microscope.

The ticks were identified morphologically using dichotomous keys (GUIMARÃES et al., 2001; BARROS-BATTESTI et al., 2006). One hundred and one ticks were deposited in the Collection of Arthropods of Medical and Veterinary Importance at the Biological Institute of São Paulo, Brazil (accession number: 1313 AMB).

DNA was extracted from one male and two female ticks using a commercial kit (DNeasy Blood \& Tissue Kit ${ }^{\mathrm{TM}}$ Qiagen $^{\circledR}$ ), following the manufacturer's instructions. Polymerase chain reaction (PCR) was performed following the manufacturer's protocol (2X DreamTaq Green PCR Master Mix), usig the primers listed in Table 1 to amplify the mitochondrial 16S rRNA gene fragment (MANGOLD et al., 1998). PCR products were purified and subjected to a commercially available standard semi-automated dideoxy Sanger sequencing method. The resulting sequences were aligned with each other and with other
Amblyomma mitochondrial 16S rRNA sequences available in the GenBank nucleotide database.

\section{Results}

The number of ticks collected from each of the 222 boa constrictors sampled ranged from 0 to 354 (mean: 28.4; standard deviation: 46.2), with a total number of 5929 ticks, of which $62 \%$ were females, $32 \%$ males and $6 \%$ nymphs. The morphological identification of the ticks collected from 27 Boa constrictor revealed the occurrence of $A$. dissimile Koch, 1844 on all the sampled individuals, whereas $A$. rotundatum Koch, 1844 was found on only two of these snakes.

The sequence of mitochondrial $16 \mathrm{~S}$ rRNA from $A$. rotundatum exhibited $99.7 \%$ identity with a fragment from the same species available in GenBank under accession number EU805569, differing in only one of the 324 base pairs sequenced. The sequence of mitochondrial 16S rRNA from $A$. dissimile exhibited $87.1 \%$ identity with the corresponding fragment from $A$. rotundatum (Figure 1) and over $90 \%$ identity with the same gene fragments from $A$. longirostre and $A$. geayi (GenBank accession numbers EU805565 and EU805566, respectively). Identity with other sequences ranged from $81.3 \%$ to $87 \%$.

Table 1. Primers used for the PCR amplification and sequencing of the mitochondrial $16 \mathrm{~S} \mathrm{rDNA}$ sequence of $A$. dissimile and $A$. rotundatum.

\begin{tabular}{cccc}
\hline PCR $_{\text {primer }} \mathbf{a}$ & Primer sequence (5'-3') & Fragment Size (bp) $^{\prime}$ & Position $^{\mathbf{b}}$ \\
\hline $16 S+1$ & CTGCTCAATGAIIIIITTAAATTGCTGTGG & $456($ A. dissimile) & $6957-7415$ \\
$16 S-1$ & TCGGTITAAACTCAGATCATGT & $449($ A. rotundatum $)$ & $6957-7415$ \\
\hline
\end{tabular}

${ }^{a}$ Modified primers described by Mangold et al. (1998). Some nucleotides were replaced with inosines to allow for the amplification of unknown genomic sequences; ${ }^{\mathrm{b}}$ Relative to the mitochondrial $A$. cajennense genome taken as reference, publicly available in GenBank under accession number JX573118.
A. rotundatum
A. dissimile
A. rotundatum
A. dissimile
A. rotundatum
A. dissimile
A. rotundatum
A. dissimile
A. rotundatum
A. dissimile
A. rotundatum
A. dissimile
A. rotundatum
A. dissimile

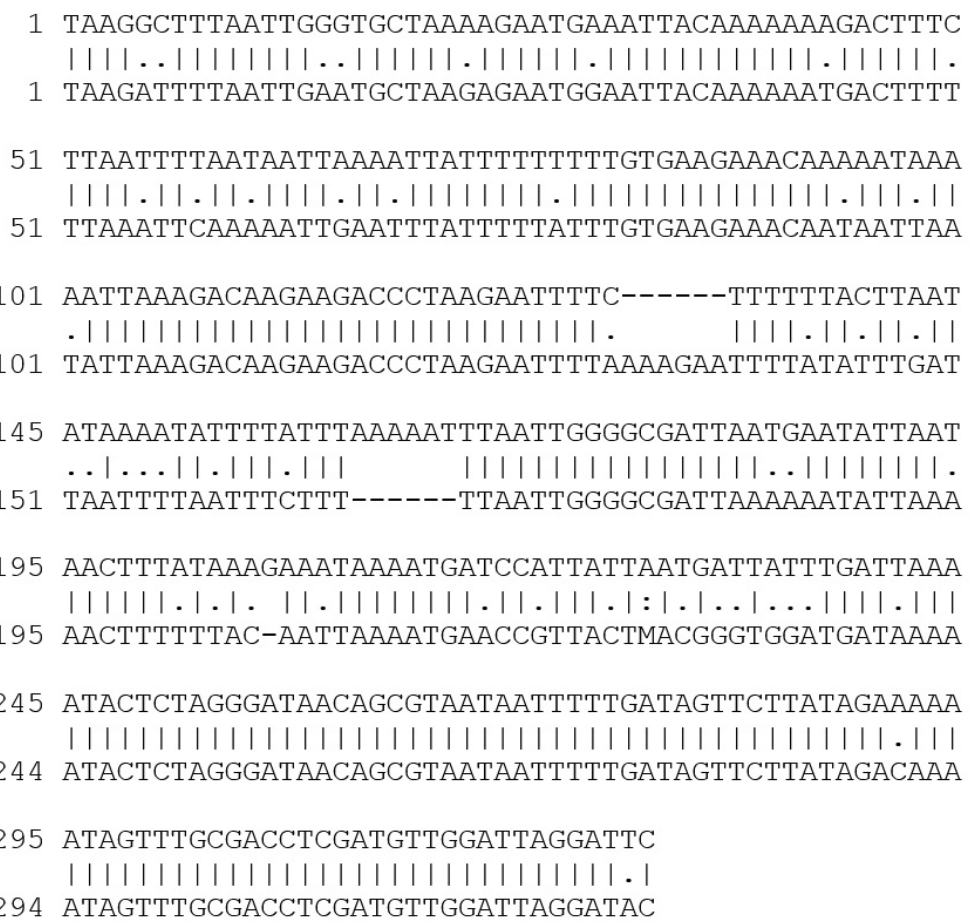

Figure 1. Mitochondrial 16S rRNA pairwise alignment with EMBOSS MATCHER program (European Bioinformatics Institute); vertical lines = identical nucleotides; horizontal lines = gaps in sequence; dots = different nucleotides. 


\section{Discussion}

The reliability of morphological features as criteria for the differentiation of $A$. dissimile from $A$. rotundatum was reinforced in this study by the analysis of a molecular marker. Mitochondrial $16 \mathrm{~S}$ rRNA is used in the comparison of individuals from the same species or different species of the same genus (MANGOLD et al., 1998). The DNA sequences of this marker among species of Amblyomma are reported to have 6.4 to $20.4 \%$ identity rates. Labruna et al. (2009) and Nava et al. (2010) studied 24 sequences of $16 \mathrm{~S}$ rRNA from Amblyomma and found identity ranging from 10 to $18 \%$. The data presented herein broaden the variation range of this marker in Amblyomma species, as 28 sequences were analyzed (Table 2).

Variations in DNA sequences encoding 16S rRNA among individuals of the same species are also common (NAVA et al., 2010), which explains the polymorphism of this marker found in the present study in comparison to the corresponding A. rotundatum sequence available in GenBank under accession number EU805569. The analysis of this marker confirmed the identification of $A$. rotundatum and $A$. dissimile and detected new

Table 2. List of publicly available mitochondrial 16S rRNA DNA sequences for pairwise alignments using the EMBOSS MATCHER program (European Bioinformatics Institute) to calculate percentage of identity.

\begin{tabular}{|c|c|}
\hline Species & GenBank Accession Number \\
\hline A. geayi & EU805566 \\
\hline A. longirostre & EU805565 \\
\hline A. brasiliense & FJ424399 \\
\hline A. incisum & FJ424405 \\
\hline A. pacae & JX141384 \\
\hline A. parkeri & JN573300 \\
\hline A. coelebs & FJ424408 \\
\hline A. naponense & FJ424406 \\
\hline A. auricularium & FJ627951 \\
\hline A. cajennense & FJ424404 \\
\hline A. maculatum & AY375442 \\
\hline A. parvum & EU543571 \\
\hline A. triste & AY498563 \\
\hline A. humerale & GQ891952 \\
\hline A. fuscum & JX141385 \\
\hline A. oblongoguttatum & FJ424407 \\
\hline A. americanum & L34314 \\
\hline A. calcaratum & JN573302 \\
\hline A. tigrinum & FJ965339 \\
\hline A. dubitatum & GU301912 \\
\hline A. aureolatum & JN573301 \\
\hline A. pseudoconcolor & AY628134 \\
\hline A. nodosum & FJ424403 \\
\hline A. goeldii & GQ891950 \\
\hline A. boeroi & JN828797 \\
\hline A. romitii & JX141383 \\
\hline A. rotundatum & EU805569 \\
\hline A. ovale & JN573304 \\
\hline
\end{tabular}

sequences in these organisms that are not found in the public database, which greatly improved our confidence in the identity of the individuals, based on morphological criteria.

This is the first record of $A$. rotundatum infesting Boa constrictor in the Amazon region. Future studies should be conducted to evaluate the ecological relationships involved in Boa constrictor populations as well as in other snake and lizard populations in the Amazon.

\section{Acknowledgments}

The authors are grateful to SEMMAS-Manaus for allowing access to the captured snakes, according to the Terms of Commitment to Scientific Research (003/2011 and 001/2012), and to the Brazilian agencies MMA, IBAMA and ICMBio for authorizing this study (SISBIO permit number: 33727-1). The ticks were collected under the auspices of the Research Project financed by MCTI/CNPq-Universal (contract 14/2011; Process 482996/2011-0).

\section{References}

Adis J. Observaçóes eco-entomológicas da Amazônia: I. Um carrapato ectoparasito da Boa constrictor. Acta Amazon 1981; 11(2): 407-410.

Barros-Battesti DM, Arzua M, Bechara GH. Carrapatos de importância médico-veterinária da região Neotropical: um guia ilustrado para identificação de espécies. São Paulo: Vox/ICTTD-3/Butantan; 2006.

Bentes AC. Avaliação do estado de conservação da população urbana de Boa constrictor (serpentes) em Manaus, Amazônia brasileira [Dissertação]. Manaus: Universidade Federal do Amazonas; 2013.

Bernarde PS. Composiçâo faunistica, ecologia e história natural de serpentes em uma região no sudoeste da Amazônia, Rondônia, Brasil [Tese de doutorado]. Rio Claro: Universidade Estadual Paulista; 2004.

Bernarde PS, Abe AS. A snake community at Espigão do Oeste, Rondônia, southwestern Amazon, Brazil. South Am J Herpetol 2006; 1(2): 102-113. http://dx.doi.org/10.2994/1808-9798(2006)1[102:AS CAED]2.0.CO;2.

Cunha OR, Nascimento FP. Ofídios da Amazônia X: as cobras da região leste do Pará. Belém: Museu Paraense Emílio Goeldi; 1978.

Davis JR, Boyle SA, Khan AA, Gay ALJ, Grisham JM, Luque LE. Snake parasitism in an urban old-growth forest. Urban Ecosyst 2012; 15(3): 739-752. http://dx.doi.org/10.1007/s11252-012-0234-7.

Guimarães JH, Tucci EC, Barros-Battesti DM. Ectoparasitos de importância veterinária. São Paulo: Plêiade; 2001.

Henderson RW, Micucci TWP, Puorto G, Bourgeois RW. Ecological correlates and patterns in the distribution of neotropical boines (Serpentes: Boidae): a preliminary assessment. Herpetol Nat Hist 1995; 3(1): 15-27.

Instituto Brasileiro de Geografia e Estatística - IBGE. Censo Demográfico 2010. Rio de Janeiro; 2012.

Labruna MB, Onofrio VC, Beati L, Arzua M, Bertola PB, Ribeiro $\mathrm{AF}$, et al. Redescription of the female, description of the male, and several new records of Amblyomma parkeri (Acari: Ixodidae), a South American tick species. Exp Appl Acarol 2009; 49(3): 243-260. http:// dx.doi.org/10.1007/s10493-009-9257-z. PMid:19241123

Mangold AJ, Bargues MD, Mas-Coma S. Mitochondrial 16S rDNA sequences and phylogenetic relationships of species of Rhipicephalus 
and other tick genera among Metastriata (Acari: Ixodidae). Parasitol Res 1998; 84(6): 478-484. http://dx.doi.org/10.1007/s004360050433. PMid:9660138

Martins M, Oliveira ME. Natural history of snakes in forests of the Manaus region, Central Amazonia, Brazil. Herpetol Nat Hist 1998; 6(2): 78-150.

Nava S, Venzal JM, Labruna MB, Mastropaolo M, González EM, Mangold AJ, et al. Hosts, distribution and genetic divergence (16S rDNA) of Amblyomma dubitatum (Acari: Ixodidae). Exp Appl Acarol 2010; 51(4): 335-351. http://dx.doi.org/10.1007/s10493-009-9331-6. PMid:20084537
Pizzatto L, Marques OAV. Reproductive ecology of boine snakes with emphasis on Brazilian species and a comparison to Pythons. South Am J Herpetol 2007; 2(2): 107-122. http://dx.doi.org/10.2994/18089798(2007)2[107:REOBSW]2.0.CO;2.

Pizzatto L, Marques OAV, Facure K. Food habits of Brazilian boid snakes: overview and new data, with special reference to Corallus hortulanus. Amphib-Reptil 2009; 30(4): 533-544. http://dx.doi. org/10.1163/156853809789647121.

Quick JS, Reinert HK, Cuba ER, Odum RA. Recent occurrence and dietary habits of Boa constrictor on Aruba, Dutch West Indies. J Herpetol 2005; 39(2): 304-307. http://dx.doi.org/10.1670/45-04N. 